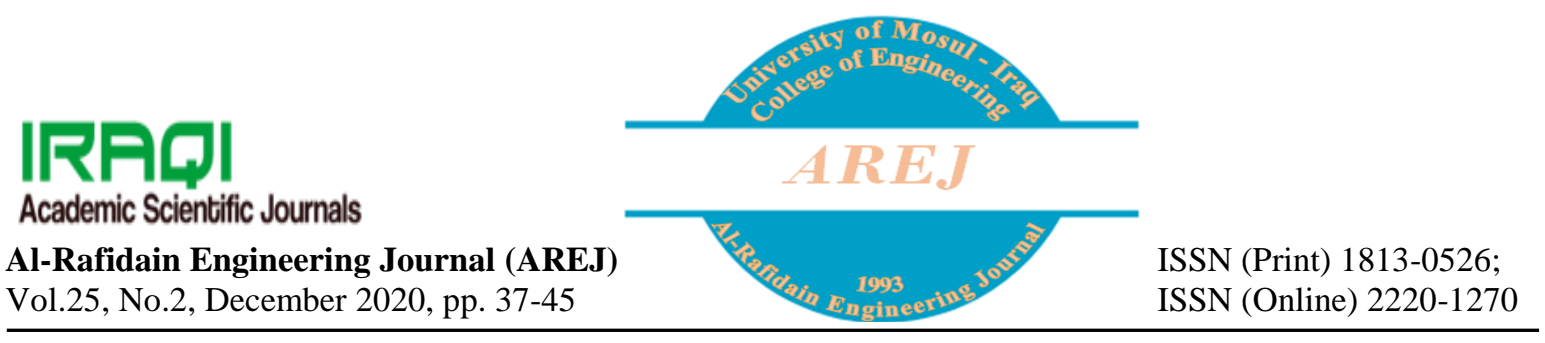

\title{
Improving the Performance of A Flat Plate Solar Collector Using Nanofluid as Working Fluid
}

\author{
Omar Mohammed Hamdoon \\ eng.omar.m.hamdoon@uomosul.edu.iq \\ Mechanical Engineering Department, Collage of Engineering, University of Mosul
}

Received: $1 / 6 / 2020$

Accepted: 5/8/2020

\begin{abstract}
Solar energy is the best alternative to limited fossil fuels. The foremost important means of utilizing solar energy are solar collectors. The most common types of solar collectors are flat plate solar collectors. A great deal of theoretical research has been conducted to enhance the flat plate solar collector efficiency. One effective way to increase the efficiency is by using an improved thermal properties fluid as nanofluid. In this paper, a numerical study has been made to enhance the efficiency and improve the performance of solar collector via the use of (Multi-Wall Carbon Nano Tube-water) MWCNT- $\mathrm{H}_{2} \mathrm{O}$ nanofluid instead of traditional fluid like water as working fluid under the weather of Mosul city / Iraq $\left(36.3489^{\circ} \mathrm{N}, 43.1577^{\circ} \mathrm{E}\right)$. One dimensional dynamic model using implicit finite difference method was used. Solving energy conservation equations through the various layers of the solar system is the basis upon which the current model was based. Effects of nanoparticle volume fraction and mass flow rate on the working fluid stream temperature differences, and the thermal efficiency were studied. The mass flow rate was varied from $0.004 \mathrm{~kg} / \mathrm{s}$ to $0.03 \mathrm{~kg} / \mathrm{s}$, while the volume fraction was varied from 0\% to 6\%. The results of "Nanofluid Based Flat Plate Solar Collector" were compared with the experimental results presented by [1]. The comparison established a good match between the current results and experimental results. The results showed an increase in the working fluid outlet and inlet temperature difference and collector thermal efficiency due to the addition of MWCNT nanoparticles. The temperature difference of "Nanofluid Based Flat Plate Solar Collector" was found $28.8^{\circ} \mathrm{C}$ at $0.014 \mathrm{~kg} / \mathrm{s}$ and $6 \%$ in April, while it was $25^{\circ} \mathrm{C}$ at the same condition in the "Water Based Flat Plate Solar Collector case". Also, the thermal efficiency of "Nanofluid Based Flat Plate Solar Collector" was found $2.41 \%$ to $6.68 \%$ more than the "Water Based Flat Plate Solar Collector case".
\end{abstract}

Keywords:

Mosul city climate, A Flat plate collector, $\mathrm{MWCNT}-\mathrm{H}_{2} \mathrm{O}$ nanofluid.

https://rengj.mosuljournals.com

Email: alrafidain_engjournal1@uomosul.edu.iq

\section{INTRODUCTION}

In the last decade, as a result of low fuel resources and environmental concerns about air pollution and international warming, increased interest in the use of solar energy has been aided by continued decline and a rapid rate of total cost of solar energy applications. Among the applications that are widely used are solar water heating systems, where solar radiation is converted into heat transmitted to the flowing water for heating. The most common collector types for solar water heating systems are flat plate solar collectors [2]. The standard flat plate solar collector consists of an insulation box with a high conductivity metal plate inside it, such as aluminium or copper called absorber plate, connected to the absorber plate tubes, and sometimes the tubes are integrated with the plate. The single or double clear glass layer is mounted on the box. The insulation box reduces heat loss from the sides of the collector or behind it. These collectors are wont to heat a liquid or air to temperatures under eighty ${ }^{\circ} \mathrm{C}$ [3]. The overall performance of the sun's collector depends on several factors, the most important of which are the thermal properties of the liquid that flows through it. Conventional fluids used in solar collectors have bad thermal properties. So many studies have tended to use another class of working fluids called 'Nanofluid' as a substitute for conventional fluids, which have improved 
thermal properties and thus increase the thermal performance of the solar collector [4]. Nanofluids consist of nanoparticles of a specific size less than 100 nanometers suspended in conventional liquids. Nanofluids have unique mechanical and thermal properties [4]. Numerous experiments were conducted by different researchers on the flat plate solar collector to test the effect of the use of nanofluids as a substitute for conventional fluids, where the results showed an increase in the rate of heat transfer in the solar collectors as a result of the use of nanofluids [5]. A study of the effect of the use of nanofluids on the thermal efficiency and size of the flat plate solar collector was conducted by Faizal et al. [6]. The researchers noted that the use of the nanofluid will increase thermal efficiency and reduce the area of solar collector. Experiments to verify the heat transfer through the flat plate solar collector using the $\mathrm{Al}_{2} \mathrm{O}_{3}$ nanofluid and at different concentrations were carried out by Said et al. [7]. Yousefi et al. [8] experimentally studied the effect of the use of $\mathrm{Al}_{2} \mathrm{O}_{3}-\mathrm{H}_{2} \mathrm{O}$ nanofluid with different nanoparticle mass fraction on the flat plate solar collector efficiency. Another experimental study on a flat plate solar collector using the MWCNT$\mathrm{H}_{2} \mathrm{O}$ nanofluid was conducted by Yousefi et al. [9]. Kabeel et al [10] theoretically studied the solar water heating system to perform the effect of adding $\mathrm{Cu}$ nanoparticles on improving the working fluid heat transfer coefficient. In this study, an estimation of the outer fluid temperatures was done. The study observed a noticeable effect of the nanofluid volume fractions on increasing the temperature of the fluid leaving the solar collector as well as the thermal efficiency. Another theoretical study was presented by Alper M. G. [11]. They proposed a transient model of flat plate solar collector at different climatic condition to study the effect of a number of factors on the performance of the solar system, including: $\mathrm{Al}_{2} \mathrm{O}_{3}$-water nanofluid volume fraction and nanofluid mass flow rates. In this study, at a mass flow rate of $0.004 \mathrm{~kg} / \mathrm{s}$ and a nanofluid volume fractions of $3 \%$, the maximum increase in the temperature of the nanofluid leaving the solar collector was 7.2\%. The effect of adding two types of $\mathrm{Al}_{2} \mathrm{O}_{3}$ and $\mathrm{CuO}$ nanoparticles with volumetric fractions between $1 \%$ and $4 \%$ was theoretically studied by M. R. Saffarian et al [12]. According to the results of the researchers, it is possible to improve the coefficient of heat transfer up to $78.25 \%$. Another factor that has been studied is the direction of nanofluids flowing into the solar collector.

The present paper aims to study the performance of the flat plate solar collector theoretically using
MWCNT-water nanofluid with different mass flow rates and volume fraction under the weather of Mosul city, Iraq using a transient onedimensional model.

\section{Mathematical model}

The dynamic model proposed by [13] for "Water Based Flat Plate Solar Collector" (WBFPSC) are going to be adopted during this section after being modified to suit the "Nanofluid Based Flat Plate Solar Collector" (NBFPSC). During this model, the control volume is chosen during the flat plate solar collector to incorporate one tube and divides the control volume perpendicular to the direction of the fluid flow into the following five nodes: glassing, air space, absorbent, working fluid, and insulation, Fig. 1. While $\mathrm{N}$ is taken from the nodes within the direction of the flow, therefore the pattern contains $(5 \times \mathrm{N})$ nodes.

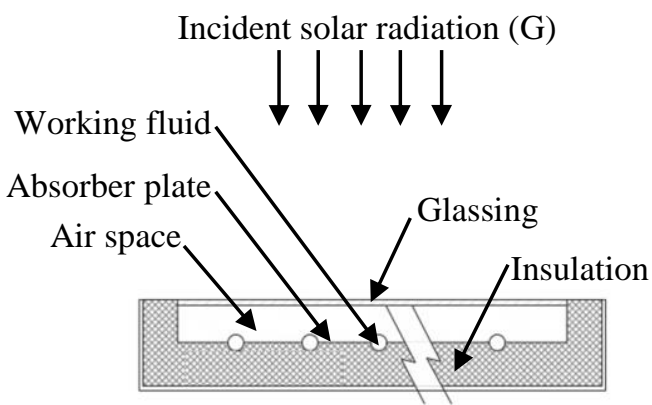

Fig. 1 Schematic diagram of flat-plate solar collector

The most important assumptions adopted in the current model are as follows:

1- The fluid flow is equal in all tubes.

2- One-dimensional heat transfer through the solar collector layers.

3- There is no heat transmitted from the edges of the solar collector.

All governing equations are derived by applying the total energy balance of each layer within the control volume [13]:

-The glass cover:

$$
\begin{aligned}
\mathrm{Cp}_{\mathrm{g}} \rho_{\mathrm{g}} \mathrm{V}_{\mathrm{g}} \frac{\mathrm{dT}}{\mathrm{dt}}=\mathrm{h}_{\mathrm{o} 1} \mathrm{~A}\left(\mathrm{~T}_{\mathrm{amb}}-\mathrm{T}_{\mathrm{g}}\right)+\alpha \mathrm{AG} \\
-\mathrm{h}_{\mathrm{c} 1} \mathrm{~A}\left(\mathrm{~T}_{\mathrm{g}}-\mathrm{T}_{\mathrm{air}}\right) \\
-\mathrm{h}_{\mathrm{r}} \mathrm{A}\left(\mathrm{T}_{\mathrm{g}}-\mathrm{T}_{\mathrm{abs}}\right)
\end{aligned}
$$

Where:

$\mathrm{Cp}_{\mathrm{g}} \rho_{\mathrm{g}} \mathrm{V}_{\mathrm{g}}$, are the specific heat, density, and volume of the glass cover.

$\alpha$ : the absorption coefficient.

$\mathrm{G}$ : the incident solar radiation.

A : the collector area.

$\mathrm{T}_{\mathrm{g}}$ : the temperature of glass cover. 
$\mathrm{T}_{\mathrm{amb}}$ : the temperature of ambient.

$\mathrm{T}_{\text {air }}$ : the temperature of air gap.

$\mathrm{T}_{\mathrm{abs}}$ : the temperature of absorber.

$\mathrm{h}_{\mathrm{r}}$ : the heat transfer coefficient by radiation [14].

Where:

$$
h_{r}=\frac{\sigma\left(T_{a b s}^{2}-T_{g}^{2}\right)\left(T_{a b s}+T_{g}\right)}{\left(1 / \varepsilon_{a b s}\right)+\left(1 / \varepsilon_{g}\right)-1}
$$

$\sigma:$ the Stefan - Boltzmann constant.

$\varepsilon_{\text {abs }}$ : the emissivity of absorber.

$\varepsilon_{\mathrm{g}}$ : the emissivity of glass cover.

$\mathrm{h}_{\mathrm{c} 1}$ : the free convection heat transfer coefficient in the inclined air gap [15].

$$
\begin{aligned}
\mathrm{h}_{\mathrm{c} 1}= & \frac{\mathrm{Nu}_{\mathrm{air}} \mathrm{k}_{\mathrm{air}}}{\mathrm{th}_{\text {air }}} \\
\mathrm{Nu}_{\mathrm{air}}=1+1.44[1 & \left.-\frac{1708[\sin (1.8 \beta)]^{1.6}}{\mathrm{R}_{\mathrm{a}} \cos (\beta)}\right] \\
& \times\left[1-\frac{1708}{\mathrm{R}_{\mathrm{a}} \cos (\beta)}\right] \\
& +\left[\left(\frac{\mathrm{R}_{\mathrm{a}} \cos (\beta)}{5830}\right)^{\frac{1}{3}}-1\right]
\end{aligned}
$$

Where:

$\mathrm{R}_{\mathrm{a}}$ : the Rayleigh number.

$\beta$ : the thermal expansion coefficient.

$\mathrm{L}$ : the length of the tube.

The equivalent heat transfer coefficient at the glass external surface, $\mathrm{h}_{\mathrm{o} 1}$, can be obtained from the following formula [14]:

Where:

$$
\mathrm{h}_{\mathrm{o} 1}=\frac{\sigma \varepsilon_{\mathrm{g}}\left(\mathrm{T}_{\mathrm{g}}^{4}-\mathrm{T}_{\mathrm{sky}}^{4}\right)}{\mathrm{T}_{\mathrm{g}}-\mathrm{T}_{\mathrm{amb}}}+\mathrm{h}_{\mathrm{c} 2}
$$

$\mathrm{T}_{\text {sky }}$ : the sky temperature, $\mathrm{T}_{\text {sky }}=0.0552 \mathrm{~T}_{\mathrm{amb}}^{1.5}$.

$\mathrm{h}_{\mathrm{c} 2}$ : the external surface convection heat transfer coefficient.

$\mathrm{h}_{\mathrm{c} 2}=\frac{\mathrm{Nu}_{\mathrm{amb}} \mathrm{k}_{\mathrm{amb}}}{\mathrm{th}}, \mathrm{Nu}_{\mathrm{amb}}=0.86 \operatorname{Re}_{\mathrm{amb}}^{1 / 2} \operatorname{Pr}_{\mathrm{amb}}^{1 / 3}$,

th $=\frac{4 \mathrm{ab}}{\sqrt{\mathrm{a}^{2}+\mathrm{b}^{2}}}$

Where:

Re : the Reynolds number.

Pr : the Prandtl number.

And $\mathrm{a}, \mathrm{b}$ are collector dimension.

-The air space layer

$$
\begin{aligned}
\mathrm{Cp}_{\text {air }} \rho_{\text {air }} \mathrm{V}_{\text {air }} \frac{\mathrm{dT}_{\text {air }}}{\mathrm{dt}} & \\
& =\mathrm{h}_{\mathrm{c} 1} \mathrm{~A}\left(\mathrm{~T}_{\mathrm{g}}-\mathrm{T}_{\text {air }}\right) \\
& -\mathrm{h}_{\mathrm{c} 1} \mathrm{~A}\left(\mathrm{~T}_{\text {air }}-\mathrm{T}_{\text {abs }}\right)
\end{aligned}
$$

Where:

$\mathrm{Cp}_{\text {air }} \rho_{\text {air }} \mathrm{V}_{\mathrm{air}}$, are the specific heat, density, and volume of the air.

- The absorber

$$
\begin{aligned}
\mathrm{Cp}_{\mathrm{abs}} \rho_{\mathrm{abs}} \mathrm{V}_{\mathrm{abs}} \frac{\mathrm{dT}_{\mathrm{abs}}}{\mathrm{dt}} & \\
& =\mathrm{h}_{\mathrm{r}} \mathrm{A}\left(\mathrm{T}_{\mathrm{g}}-\mathrm{T}_{\mathrm{abs}}\right)+(\tau \alpha) \mathrm{A} \mathrm{G} \\
& +\mathrm{h}_{\mathrm{c} 1} \mathrm{~A}\left(\mathrm{~T}_{\mathrm{air}}-\mathrm{T}_{\mathrm{abs}}\right) \\
& -\frac{\mathrm{k}_{\text {ins }}}{\mathrm{th}_{\text {ins }}} \mathrm{A}\left(\mathrm{T}_{\mathrm{abs}}-\mathrm{T}_{\mathrm{ins}}\right) \\
& -\mathrm{h}_{\mathrm{nf}} \mathrm{A}_{\mathrm{s}}\left(\mathrm{T}_{\mathrm{abs}}-\mathrm{T}_{\mathrm{f}}\right) \quad \ldots(3)
\end{aligned}
$$

Where:

$\mathrm{Cp}_{\mathrm{abs}} \rho_{\mathrm{abs}} \mathrm{V}_{\mathrm{abs}}$, are the specific heat, density, and volume of the absorber.

$A_{s}:$ the pipe cross sectional area.

$\tau \alpha$ : the effective transmittance absorption coefficient.

$\mathrm{T}_{\mathrm{f}}$ : the temperature of working fluid.

$\mathrm{T}_{\text {ins }}$ : the temperature of insulation.

$\mathrm{k}_{\mathrm{ins}}$ : the insulation thermal conductivity.

$\mathrm{th}_{\text {ins }}$ : the insulation layer thickness.

$\mathrm{h}_{\mathrm{nf}}$ : the nanofluid heat transfer coefficient.

- $\quad$ The working fluid

$$
\begin{aligned}
\operatorname{Cp}_{n f} \rho_{n f} A_{f} \frac{\partial T_{f}}{\partial t}= & \pi h_{n f} d_{i n}\left(T_{a b s}-T_{f}\right) \\
& -m_{f} \operatorname{Cp}_{n f} \frac{\partial T_{f}}{\partial z} \quad \ldots
\end{aligned}
$$

Where:

$A_{f}$ : the cross sectional area of the tube.

$d_{i n}:$ the inner diameter of the tube.

$\mathrm{m}_{\mathrm{f}}$ : the nanofluid mass flowrate per tube.

$\mathrm{Cp}_{\mathrm{nf}}$ : the specific heat of nanofluid.

$\rho_{\mathrm{nf}}$ : the density of nanofluid.

These nanofluid properties are evaluated using the following correlations:

Density of nanofluid can be estimated from Pak and Cho's equation [16] as:

Where:

$$
\rho_{\mathrm{nf}}=(1-\phi) \rho_{\mathrm{bf}}+\phi \rho_{\mathrm{p}}
$$

$\phi:$ the nanofluid volume fraction.

$\rho_{\mathrm{bf}}:$ the density of the water.

$\rho_{b}$ : the density of the MWCNT nanoparticle's.

The specific heat of nanofluid given as [16]:

Where:

$$
C p_{n f}=\frac{(1-\phi) \rho_{\mathrm{bf}} \mathrm{Cp}_{\mathrm{bf}}+\phi \rho_{\mathrm{p}} \mathrm{C} \mathrm{p}_{\mathrm{p}}}{\rho_{\mathrm{nf}}}
$$

$C p_{p}$ : the specific heat of MWCNT nanoparticle's $\mathrm{Cp}_{\mathrm{bf}}:$ the water specific heat.

The heat transfer coefficient of Nanofluid or water is given as:

$$
\mathrm{h}=\frac{\mathrm{Nu} \mathrm{k}}{\mathrm{d}_{\mathrm{in}}}
$$

Using Dittus-Boelter correlation [17], Nusselt number $(\mathrm{Nu})$ for the water flowing inside the pipe is obtained, where the Nusselt number for nanofluid is obtained by using the formula of Xuan and Li [18] as follows:

For $\operatorname{Re}<2300$ 
$\mathrm{Nu}_{\mathrm{nf}}=0.4328\left(1+11.285 \phi^{0.745} \mathrm{P}_{\mathrm{e}}^{0.218}\right) \mathrm{R}_{\mathrm{e}}^{0.333} \mathrm{P}_{\mathrm{r}}^{0.4}$ For $2300<\operatorname{Re}<25000$

$\mathrm{Nu}_{\mathrm{nf}}=0.0059\left(1+7.628 \phi^{0.6886} \mathrm{P}_{\mathrm{e}}^{0.001}\right) \mathrm{R}_{\mathrm{e}}^{0.9238} \mathrm{P}_{\mathrm{r}}^{0.4}$ Where $P_{e}$ is the Peclet number which is defined as:

Where:

$$
P_{e}=\frac{U_{m} d_{p}}{\alpha_{n f}}
$$

$\mathrm{d}_{\mathrm{p}}$ : the nanoparticle diameter.

$\mathrm{U}_{\mathrm{m}}$ : the nanofluid mean velocity

$\alpha_{\mathrm{nf}}$ : the thermal diffusivity for the nanofluid.

The thermal conductivity of nanofluid can be estimated from the following equation [16]:

$$
\mathrm{k}_{\mathrm{nf}}=\mathrm{k}_{\mathrm{bf}} \frac{\mathrm{k}_{\mathrm{p}}+(\mathrm{n}-1) \mathrm{k}_{\mathrm{bf}}-(\mathrm{n}-1) \phi\left(\mathrm{k}_{\mathrm{bf}}-\mathrm{k}_{\mathrm{p}}\right)}{\mathrm{k}_{\mathrm{p}}+(\mathrm{n}-1) \mathrm{k}_{\mathrm{bf}}+\phi\left(\mathrm{k}_{\mathrm{bf}}-\mathrm{k}_{\mathrm{p}}\right)}
$$

Where:

$\mathrm{k}_{\mathrm{p}}$ : the thermal conductivity of nanoparticles. $\mathrm{k}_{\mathrm{bf}}$ : the thermal conductivity of of the base fluid. $\mathrm{n}$ : the shape factor $(\mathrm{n}=3 / \psi)$, and $\psi$ is the particle sphericity.

- The insulation

$$
\begin{aligned}
& \mathrm{Cp}_{\text {ins }} \rho_{\text {ins }} \mathrm{V}_{\mathrm{ins}} \frac{\mathrm{dT}_{\mathrm{ins}}}{\mathrm{dt}}=\frac{\mathrm{k}_{\text {ins }}}{\mathrm{th}_{\text {ins }}} \mathrm{A}\left(\mathrm{T}_{\mathrm{abs}}-\mathrm{T}_{\mathrm{ins}}\right)- \\
& \mathrm{h}_{\mathrm{o} 2} \mathrm{~A}\left(\mathrm{~T}_{\mathrm{ins}}-\mathrm{T}_{\mathrm{amb}}\right)
\end{aligned}
$$

Where:

$\mathrm{Cp}_{\text {ins }} \rho_{\text {ins }} \mathrm{V}_{\text {ins }}$, are the insulation layer specific heat, density, and volume.

$\mathrm{h}_{\mathrm{o} 2}$ : the equivalent heat transfer coefficient at the outside surface of the insulation.

The implicit finite difference method was used to solve the system of differential equations, and the forward and backward difference scheme were used instead of the dimensional and time derivatives. The final formula of the equation system is:

$$
\begin{aligned}
& \mathrm{T}_{\mathrm{g}} \\
& =\left[\frac{\mathrm{T}_{\mathrm{g}}^{\mathrm{old}}}{\Delta \mathrm{t}}+\mathrm{A}_{1} \mathrm{~T}_{\mathrm{amb}}+\mathrm{A}_{2} \mathrm{~T}_{\mathrm{air}}+\mathrm{A}_{3} \mathrm{~T}_{\mathrm{abs}}+\mathrm{A}_{4} \mathrm{G}\right] / \mathrm{A}_{5}
\end{aligned}
$$

$\mathrm{T}_{\text {air }}$

$$
\begin{aligned}
& =\left[\frac{\mathrm{T}_{\text {air }}^{\text {old }}}{\Delta \mathrm{t}}+\mathrm{A}_{6} \mathrm{~T}_{\mathrm{g}}+\mathrm{A}_{6} \mathrm{~T}_{\mathrm{abs}}\right] / \mathrm{A}_{7} \\
& \mathrm{~T}_{\text {abs }} \\
& =\left[\begin{array}{c}
\frac{\mathrm{T}_{\mathrm{abs}}^{\text {old }}}{\Delta \mathrm{t}}+\mathrm{A}_{8} \mathrm{~T}_{\mathrm{g}}+\mathrm{A}_{9} \mathrm{~T}_{\text {air }}+\mathrm{A}_{10} \mathrm{G}+\mathrm{A}_{11} \mathrm{~T}_{\mathrm{ins}} \\
+\mathrm{A}_{12} \mathrm{~T}_{\mathrm{f}}
\end{array}\right] / \mathrm{A}_{13}
\end{aligned}
$$

\begin{tabular}{|c|c|}
\hline $\mathrm{A}_{1}=\mathrm{h}_{\mathrm{o} 1} / \mathrm{Cp}_{\mathrm{g}} \rho_{\mathrm{g}} \mathrm{th}_{\mathrm{g}}$ & $\mathrm{A}_{2}=\mathrm{h}_{\mathrm{c} 1} / \mathrm{Cp}_{\mathrm{g}} \rho_{\mathrm{g}} \mathrm{th}_{\mathrm{g}}$ \\
\hline $\mathrm{A}_{3}=\mathrm{h}_{\mathrm{r}} / \mathrm{Cp}_{\mathrm{g}} \rho_{\mathrm{g}} \mathrm{th}_{\mathrm{g}}$ & $\mathrm{A}_{4}=\alpha / \mathrm{Cp}_{\mathrm{g}} \rho_{\mathrm{g}} \mathrm{th}_{\mathrm{g}}$ \\
\hline $\mathrm{A} 5=(1 / \Delta \mathrm{t})+\mathrm{A} 1+\mathrm{A} 2+\mathrm{A} 3$ & $\mathrm{~A}_{6}=\mathrm{h}_{\mathrm{c} 1} / \mathrm{Cp}_{\text {air }} \rho_{\text {air }} \overline{\mathrm{h}}_{\mathrm{air}}$ \\
\hline $\mathrm{A} 7=(1 / \Delta \mathrm{t})+2 \mathrm{~A} 6$ & $\begin{array}{l}\mathrm{A}_{8} \\
=\mathrm{h}_{\mathrm{r}} \mathrm{p} / \mathrm{Cp}_{\mathrm{abs}} \rho_{\mathrm{abs}} \overline{\mathrm{t}}_{\mathrm{abs}}\end{array}$ \\
\hline $\mathrm{A}_{9}=\mathrm{h}_{\mathrm{c} 1} \mathrm{p} / \mathrm{Cp}_{\mathrm{abs}} \rho_{\mathrm{abs}} \mathrm{t} \overline{\mathrm{h}}_{\mathrm{abs}}$ & $\begin{array}{l}\mathrm{A}_{10} \\
=(\tau \alpha) \mathrm{p} / \mathrm{Cp}_{\mathrm{abs}} \rho_{\mathrm{abs}} \overline{\mathrm{h}}_{\mathrm{abs}}\end{array}$ \\
\hline $\begin{array}{l}\mathrm{A}_{11} \\
=\mathrm{k}_{\mathrm{ins}} \mathrm{p} / \mathrm{Cp}_{\mathrm{abs}} \rho_{\mathrm{abs}} \overline{\mathrm{h}}_{\mathrm{abs}} \mathrm{th} \text { ins }\end{array}$ & $\begin{array}{l}\mathrm{A}_{12} \\
=\pi \mathrm{d}_{\mathrm{in}} \mathrm{h}_{\mathrm{c} 1} / \mathrm{Cp}_{\mathrm{abs}} \rho_{\mathrm{abs}} \overline{\mathrm{th}}_{\mathrm{ab}}\end{array}$ \\
\hline $\begin{array}{l}\text { A13 } \\
=(1 / \Delta t)+A 8+A 9+A 11+A 12\end{array}$ & $\mathrm{~A}_{14}=\pi \mathrm{d}_{\mathrm{in}} \mathrm{h}_{\mathrm{f}} / \mathrm{Cp}_{\mathrm{f}} \rho_{\mathrm{f}} \mathrm{A}_{\mathrm{f}}$ \\
\hline $\mathrm{A}_{15}=\mathrm{m}_{\mathrm{f}} / \rho_{\mathrm{f}} \mathrm{A}_{\mathrm{f}}$ & $\mathrm{A} 16=(1 / \Delta \mathrm{t})+\mathrm{A} 14 \mathrm{~A} 15$ \\
\hline $\mathrm{A}_{17}=\mathrm{k}_{\mathrm{ins}} / \mathrm{Cp}_{\mathrm{ins}} \rho_{\mathrm{ins}} \mathrm{th}_{\mathrm{ins}}^{2}$ & $\begin{array}{l}\mathrm{A}_{18} \\
=\mathrm{h}_{\mathrm{o} 2} / \mathrm{Cp}_{\mathrm{ins}} \rho_{\text {ins }} \mathrm{th}_{\mathrm{ins}}\end{array}$ \\
\hline $\mathrm{A} 19=(1 / \Delta \mathrm{t})+\mathrm{A} 17+\mathrm{A} 18$ & \\
\hline
\end{tabular}

$\mathrm{T}_{\mathrm{f}}$

$$
=\left[\frac{\mathrm{T}_{\mathrm{f}}^{\text {old }}}{\Delta \mathrm{t}}+\mathrm{A}_{14} \mathrm{~T}_{\mathrm{abs}}+\frac{\mathrm{A}_{15}}{\Delta \mathrm{z}} \mathrm{T}_{\mathrm{f}, \mathrm{j}-1}\right] / \mathrm{A}_{16}
$$

$$
\begin{aligned}
& \mathrm{T}_{\text {ins }} \\
& =\left[\frac{\mathrm{T}_{\text {ins }}^{\text {old }}}{\Delta \mathrm{t}}+\mathrm{A}_{17} \mathrm{~T}_{\mathrm{abs}}+\mathrm{A}_{18} \mathrm{~T}_{\mathrm{amb}}\right] / \mathrm{A}_{19} \ldots .
\end{aligned}
$$

The criterion of performance of the solar collector in current study is the difference between the temperature of the working fluid outlet and inlet temperatures difference, in addition to the efficiency of the solar collector. The thermal efficiency $(\eta)$ of the solar collector can be defined as the heat that the fluid gained during the solar collector to the total solar radiation incident on the surface area of the collector.

$$
\eta=\frac{m_{f} C p_{f}\left(T_{o}-T_{i}\right)}{A G}
$$

\section{Solution Method:}

An itemized description of solution steps of the flat plate solar collector model is presented below:

1. Stepping along the length of the wheel channel ( $\mathrm{z}$ direction), the temperatures of: glass cover (eq.6), air gap (eq.7), absorber (eq.8), working fluid (eq.9), and insulation layers (eq.10), are computed incrementally.

2. The temperatures are stored. These temperatures will be used as "previous" temperature in the next time step. 
3. Steps 1 and 2 are repeated for each time step until getting the required convergence $\left(\mathrm{T}_{\mathrm{j}}-\mathrm{T}_{\mathrm{j}}^{\mathrm{old}} / \mathrm{T}_{\mathrm{j}}\right) \leq \varepsilon_{\text {error }}$.

4. The final temperature is recorded and used to find the performance.

The variables estimation is stopped when achieve convergence with the convergence criterion set to $\left(\varepsilon_{\text {error }}=1.0 \times 10^{-4}\right)$. During this work, FORTRAN 90 (Microsoft Developer studio Copy right@ 19941995) has been utilized to develop the code.

\section{Model Validation.}

A comparison of simulation results with experimental results presented by [1] was made to confirm the validity of the current model. Experimentally investigated at the Razi University of Kermanshah, Iran (latitude is $34^{\circ} 20^{\prime} 56^{\prime \prime} \mathrm{N}$ and longitudeis $7^{\circ} 9^{\prime} 20^{\prime \prime} \mathrm{E}$ ). The major design information used in the comparison, are given in Table 1.

Table 1: Parameters used in solar collector validation

\begin{tabular}{|c|c|}
\hline Specifications & Detail \\
\hline $\begin{array}{c}\text { Dimension of the } \\
\text { collector }\end{array}$ & $2 \times 1 \times 0.95 \mathrm{~m}$ \\
\hline Material of the tubes & Copper \\
\hline Tubes number & 9 \\
\hline Diameter of the tubes & $0.0125 \mathrm{~m}$ \\
\hline Material of the absorber & Aluminum \\
\hline $\begin{array}{c}\text { Thickness of the glass } \\
\text { cover }\end{array}$ & $0.004 \mathrm{~m}$ \\
\hline Air space thickness & $0.025 \mathrm{~m}$ \\
\hline Collector title angle & $45^{\circ}$ \\
\hline Working fluid & MWCNT-water \\
\hline Mass fraction & $0.2 \%$ \\
\hline Fluid mass flow rate & $0.05 \mathrm{~kg} / \mathrm{s}$ \\
\hline
\end{tabular}

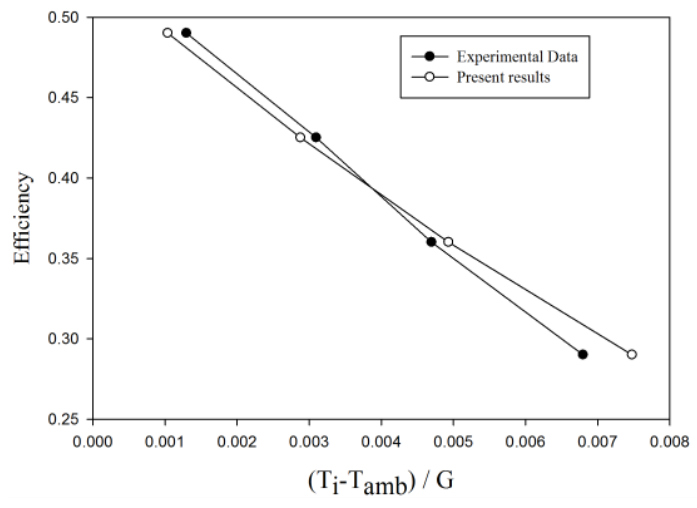

Fig. 2 NBFPSC model validation.
Results of the comparison are pictured in Fig. 2. Fig. 2 show that the present model gives good congruence with experimental data. The maximum difference in the values between the results of the present model and experiment of data is about $(8 \%)$, which confirms accuracy of the present model.

\section{Simulation results}

This section explores the simulation results and the remarks concluded from those result. The design descriptions of the flat plate solar collector and the operating conditions will be presented before discussing the simulation results.

Table 2: The NBFPSC model description and operating condition:

\begin{tabular}{|c|c|}
\hline $\begin{array}{c}\text { Collector parameters } \\
\text { collector }\end{array}$ & Detail \\
\hline $\begin{array}{c}\text { Dimension of the } \\
\text { Material of the tubes }\end{array}$ & Copper \\
\hline Tubes number & 9 \\
\hline $\begin{array}{c}\text { Tubes inner and outer } \\
\text { diameters }\end{array}$ & $0.01,0.0125 \mathrm{~m}$ \\
\hline Material of the absorber & Aluminum \\
\hline $\begin{array}{c}\text { Back insulation } \\
\text { thickness }\end{array}$ & $0.025 \mathrm{~m}$ \\
\hline Glass thickness & $0.004 \mathrm{~m}$ \\
\hline Air space thickness & $0.025 \mathrm{~m}$ \\
\hline Collector title angle & $31^{\circ}$ \\
\hline Working fluid & MWCNT- $\mathrm{H}_{2} \mathrm{O}$, \\
\hline water \\
\hline Mass flow rate & 0.004 to $0.03 \mathrm{~kg} / \mathrm{s}$ \\
\hline
\end{tabular}

The values of solar radiation falling on the solar collector (G) at different hours of the day, in addition to the average ambient temperature were found for Mosul city, Iraq $\left(36.348^{\circ} \mathrm{N}, 43.1577^{\circ} \mathrm{E}\right)$ from the website "Photovoltaic Geographical Information System (PVGIS)" [19]. These data for tilted surface collector $\left(\theta=31^{\circ}\right.$, south orientation) are presented graphically in Figures 3 to 6. From Fig. 3, it can seen in a typical day in January, the average ambient temperature varies between 3 to $12^{\circ} \mathrm{C}$, where the incident radiation varies between 0 to $570 \mathrm{~W} / \mathrm{m}^{2}$. Fig. 4 show that in a typical day in April the average ambient temperature varies between 13.5 to $25.5^{\circ} \mathrm{C}$, where the incident radiation varies between 0 to 846 $\mathrm{W} / \mathrm{m}^{2}$. In a typical day in July Fig. 5 show that the average ambient temperature varies between 29 to $42.5^{\circ} \mathrm{C}$, where the incident radiation varies 
between 0 to $988 \mathrm{~W} / \mathrm{m}^{2}$, whereas in typical day in October Fig. 6 show that the average ambient temperature varies between 18 to $29.9^{\circ} \mathrm{C}$, where the incident radiation varies between 0 to 827.5 $\mathrm{W} / \mathrm{m}^{2}$.

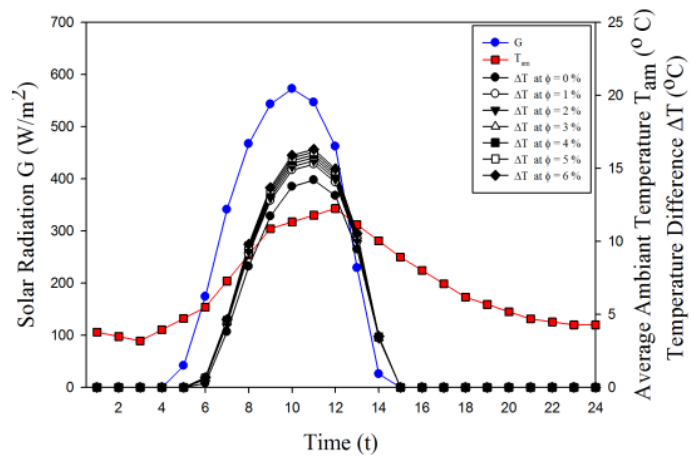

Fig. 3 Variation of hourly solar radiation on the solar collectors, ambient temperature and working fluid temperature differences as a function of nanoparticle volume fraction during a typical day in January.

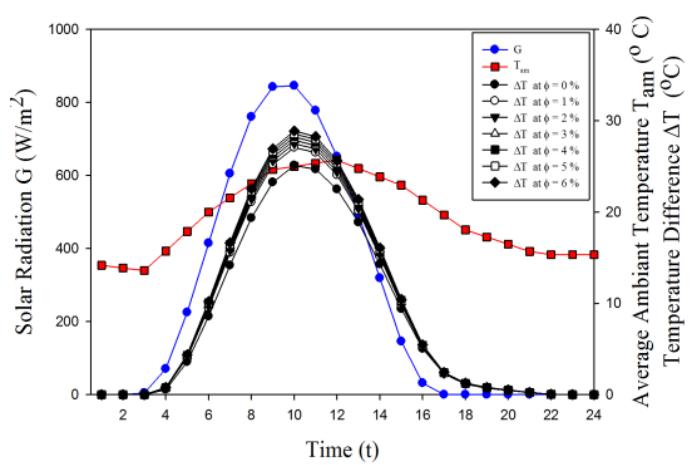

Fig. 4 Variation of hourly solar radiation on the solar collectors, ambient temperature and working fluid temperature differences as a function of nanoparticle volume fraction during a typical day in April.

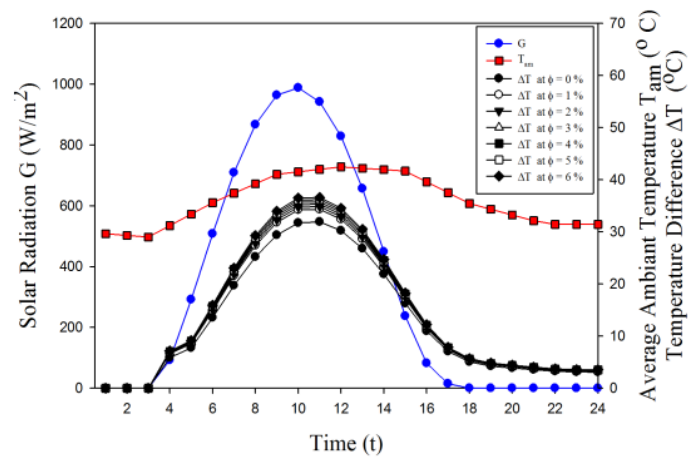

Fig. 5 Variation of hourly solar radiation on the solar collectors, ambient temperature and working fluid temperature differences as a function of nanoparticle volume fraction during a typical day in July.

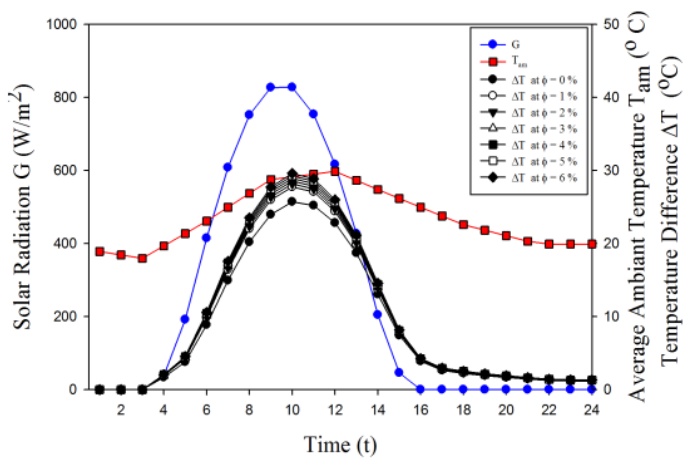

Fig. 6 Variation of hourly solar radiation on the solar collectors, ambient temperature and working fluid temperature differences as a function of nanoparticle volume fraction during a typical day in October.

Figures 3 to 6 also show the hourly variation of working fluid outlet and inlet temperatures difference $(\Delta T)$ variance as a function of nanoparticle volume fraction. The working fluid mass flow rate will be assumed constant at $(0.014$ $\mathrm{kg} / \mathrm{s}$ ) while its inlet temperature will be assumed similar to the city water temperature which has the values shown in the fig. 7 [20].

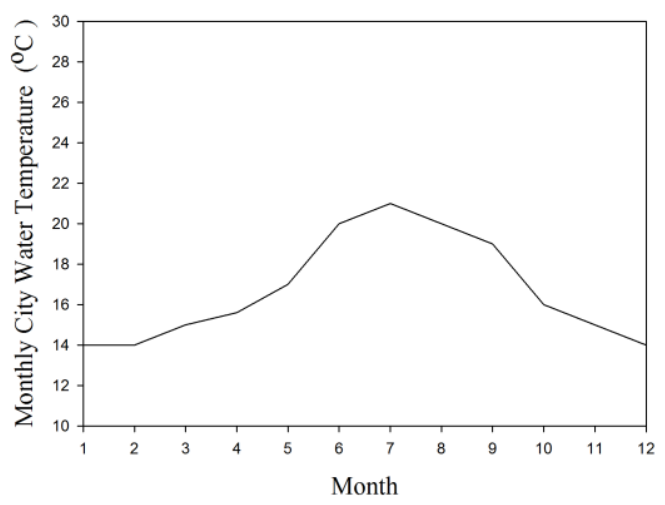

Fig. 7 Monthly city water temperature profile in Mosul city.

From the Figures it can seen that the temperatures difference $(\Delta T)$ increase as time and volume fraction increase. The temperatures difference $(\Delta \mathrm{T})$ follow the pattern of solar radiation with some delay the maximum temperature difference occurred before noon and minimum in morning and evening. The Figures also show that the addition of nanoparticles increase the temperature difference. For example, in the case of (NBFPSC) the maximum temperature differences were $\left(16.3^{\circ} \mathrm{C}\right),\left(28.8^{\circ} \mathrm{C}\right),\left(36.5^{\circ} \mathrm{C}\right)$ and $\left(29.5^{\circ} \mathrm{C}\right)$ at a volume fraction of $(6 \%)$ in a typical days in 
January, April, July and October respectively, whereas in the case of (WBFPSC), maximum temperature differences were $\left(14^{\circ} \mathrm{C}\right),\left(25^{\circ} \mathrm{C}\right)$, $\left(31.9^{\circ} \mathrm{C}\right)$ and $\left(22.8^{\circ} \mathrm{C}\right)$ at a volume fraction of $(6 \%)$ in a typical days in January, April, July and October respectively. The explanation for this can be illustrated by the following: The increase in nanoparticle volume fraction will increase both the density of nanofluid, thermal conductivity, and viscosity, which will increase the heat transfer coefficient. The temperature differences lines in the case of (NBFPSC) are very close to each other, for example the maximum temperature differences were $\left(1^{\circ} \mathrm{C}\right),\left(1.8^{\circ} \mathrm{C}\right)$, $\left(2.29^{\circ} \mathrm{C}\right)$ and $\left(1.8^{\circ} \mathrm{C}\right)$ in a typical days in January, April, July and October respectively In Fig. 8, thermal efficiencies are given at the working fluid mass flow rate between $0.004 \mathrm{~kg} / \mathrm{s}$ to $0.03 \mathrm{~kg} / \mathrm{s}$ in April with different nanoparticle volume fractions. It can be seen that the efficiency increase with increasing mass flow rate for (NBFPSC) and (WBFPSC) cases. At high flow rate, the addition of nanoparticles to the water leads to an improvement in efficiency with a higher rate than the low flow status. For example, the addition of nanoparticles led to an increase in efficiency between $(2.41 \%)$ to $(2.91 \%)$ at flow rate $(0.004 \mathrm{~kg} / \mathrm{s})$, while adding nanoparticles led to an increase in efficiency between $(4.67 \%)$ at flow rate $(6.68 \%)$ at flow rate $(0.03 \mathrm{~kg} / \mathrm{s})$.

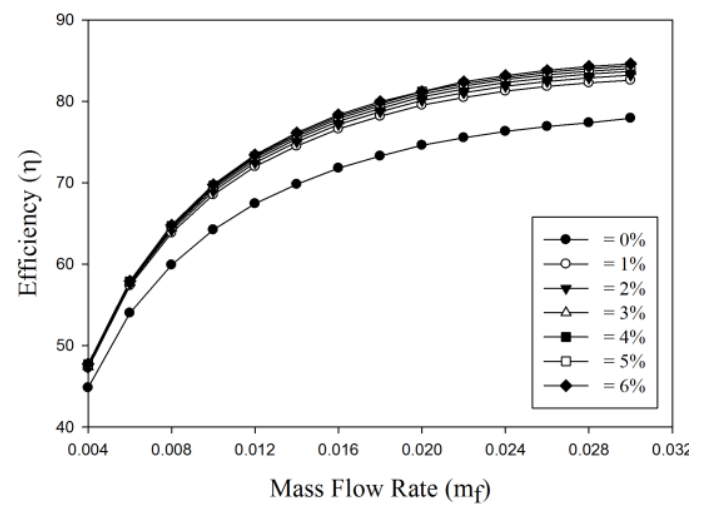

Fig. 8 Average thermal efficiency for (WBFPSC) and (NBFPSC) as a function of working fluid mass flow rates during a typical

\section{Conclusion}

In this study, the one dimensional dynamic model of MWCNT- $\mathrm{H}_{2} \mathrm{O}$ nanofluid based flat plate solar collector for different nanoparticles volume fraction and mass flow rate at Mosul city, Iraq climatic condition. The main conclusion are summarized as follow:

- A noticeable increase in the working fluid outlet and inlet temperature differences through solar collector obtained by adding nanoparticles for the four selected months.

- Changing the values of nanoparticle volume fraction between $1 \%$ to $6 \%$ led to a limited increase in the working fluid outlet and inlet temperatures difference and thermal efficiency.

- The working fluid mass flow rate has a significant impact on increasing the (NBFPSC) and (WBFPSC) efficiencies, but the rate of increase varies according to the flow rate. Whereat high flowrate, adding nanoparticles to water improved efficiency at a rate higher than low flow condition.

\section{Nomenclature}

A

$\mathrm{a} \times \mathrm{b}$

$\mathrm{A}_{\mathrm{s}}$

$\mathrm{Cp}$

$\mathrm{d}_{\mathrm{p}}$

G

h

$\mathrm{h}_{\mathrm{c} 1}$

$\mathrm{h}_{\mathrm{c} 2}$

$\mathrm{h}_{\mathrm{o} 1}$

$\mathrm{hr}$

$\mathrm{P}_{\mathrm{e}}$

$\operatorname{Pr}$

$\mathrm{R}_{\mathrm{a}}$

$\mathrm{R}_{\mathrm{e}}$

$\mathrm{T}$

th

$\mathrm{T}_{\text {sky }}$
Collector area, $\mathrm{m}^{2}$.

Collector dimension, $\mathrm{m} \times \mathrm{m}$.

Pipe cross sectional area, $\mathrm{m}^{2}$.

Specific heat, J/kg.K.

Nanoparticle diameter, $m$.

Incident solar radiation, $\mathrm{W} / \mathrm{m}^{2}$.

Working fluid heat transfer coefficient, $\mathrm{W} / \mathrm{m}^{2} . \mathrm{K}$.

Heat transfer coefficient in the inclined air space, $\mathrm{W} / \mathrm{m}^{2} . \mathrm{K}$.

Heat transfer coefficient on the external surface of the cover, $\mathrm{W} / \mathrm{m}^{2} . \mathrm{K}$.

Equivalent heat transfer coefficient on the external surface of the glass, $\mathrm{W} / \mathrm{m}^{2} . \mathrm{K}$.

Radiation heat transfer coefficient between the absorber and glass cover, $\mathrm{W} / \mathrm{m}^{2} . \mathrm{K}$.

Node number.

Working fluid mass flow rate, $\mathrm{kg} / \mathrm{s}$.

Nusselt number.

Peclet number.

Prandtl number.

Rayleigh number.

Reynolds number.

Temperature, $\mathrm{K}$.

Thickness, $\mathrm{m}$.

Sky temperature, $\mathrm{K}$. 
V

$\mathrm{Z}$

\section{Greek Symbols}

\begin{tabular}{|c|c|}
\hline & Absorption coefficient. \\
\hline & $\begin{array}{l}\text { Thermal expansion } \\
\text { coefficient. } \\
\text { Collector thermal efficiency. }\end{array}$ \\
\hline & Collector title angle, degree. \\
\hline & Density, $\mathrm{kg} / \mathrm{m}^{3}$. \\
\hline & $\begin{array}{l}\text { Stefan-Boltzmann constant }= \\
5.67 \times 10-8 \mathrm{~W} / \mathrm{m}^{2} \cdot \mathrm{K}^{4} . \\
\text { Transmissivity. }\end{array}$ \\
\hline & $\begin{array}{l}\text { Particle's volume fraction in } \\
\text { the nanofluid. }\end{array}$ \\
\hline
\end{tabular}

\section{Subscripts}

$\begin{array}{ll}\text { abs } & \text { Absorber. } \\ \text { air } & \text { Air gap. } \\ \text { am } & \text { Ambient. } \\ \text { bf } & \text { Base fluid. } \\ \mathrm{f} & \text { Working fluid. } \\ \mathrm{g} & \text { Glass cover. } \\ \mathrm{i}, \mathrm{o} & \text { Inlet and outlet working fluid. } \\ \text { ins } & \text { Insulation. } \\ \mathrm{p} & \text { Nanoparticles. }\end{array}$

\section{REFERENCE}

[1] T. Yousefi, E. Shojaeizadeh, F. Veysi, S. Zinadini, "An experimental investigation on the effect of $\mathrm{pH}$ variation of MWCNT- $\mathrm{H}_{2} \mathrm{O}$ nanofluid on the efficiency of a flat-plate solar collector", Solar Energy, Vol. 86, pp. 771-779, 2012.

[2] E. Ekramian, S. Gh. Etemad, M. Haghshenasfard, "Numerical Investigations of Heat Transfer Performance of Nanofluids in a Flat Plate Solar Collector", International Journal of Theoretical and Applied Nanotechnology, Vol. 2, pp. 19291248, 2014.

[3] A. M. Saleh, "Modeling of flat plate solar collector operation in transient states", Purdue University, M.Sc Thesis, May 2012.

[4] L. Kundan, P. Sharma, "Performance Evaluation of a Nanofluid $\left(\mathrm{CuO}-\mathrm{H}_{2} \mathrm{O}\right)$ Based Low Flux Solar Collector", International Journal of Engineering Research, Vol. 2, Issue: 2, pp. 108-112, 2013.

[5] Barot Vishalkumar G and K.D Panchal, "Nanofluid : A Tool to Increase the Efficiency of Solar Collector", International Journal of Innovation in Engineering and Technology, Vol. 5, Issue: 5, pp. 350-355, 2015.
[6] M. Faizal, R. Saidur, S. Mekhilef, M.A. Alim, "Energy, economic and environmental analysis of metal oxides nanofluid for flat-plate solar collector", Energy Conversion Management, Vol. 76, pp. 162-168, 2013.

[7] Z. Said, M.H. Sajid, M.A. Alim, R. Saidur, N.A. Rahim, "Experimental investigation of the thermophysical properties of $\mathrm{Al}_{2} \mathrm{O}_{3}$-nanofluid and its effect on a flat plate solar collector", International Communications in Heat and Mass Transfer, Vol. 48, pp. 99-107, 2013.

[8] T. Yousefi, F. Veysi, E. Shojaeizadeh, and S. Zinadini, "An experimental investigation on the effect of $\mathrm{Al}_{2} \mathrm{O} 3-\mathrm{H}_{2} \mathrm{O}$ nanofluid on the efficiency of flat-plate solar collectors", Renewable Energy, Vol. 39, pp. 293-298, 2012.

[9] T. Yousefi, F. Veisy, E. Shojaeizadeh, and S. Zinadini, "An experimental investigation on the effect of MWCNT- $\mathrm{H}_{2} \mathrm{O}$ nanofluid on the efficiency of flat-plate solar collectors", Experimental Thermal and Fluid Science, Vol. 39, pp. 207-212, 2012.

[10] A. E. Kabeel, Emad M. S. El-Said, S. A. ElAgouz, "A theoretical study of $\mathrm{Cu}-\mathrm{H}_{2} \mathrm{O}$ nanofluid effect on heat transfer enhancement of a solar water heater", International Journal of Ambient Energy, Vol. 38, pp. 286-294, 2017.

[11] A. M. Genc, M. A. Ezan, A. Turgut, "Thermal performance of a nanofluid-based flat plate solar collector: A transient numerical study", Applied Thermal Engineering, Vol. 130, pp. 395-407, 2018.

[12] M. R. Saffarian, M. Moravej, M. H. Doranehgard, "Heat transfer enhancement in a flat plate solar collector with different flow path shapes using nanofluid", Renewable Energy, Vol. 146, pp. 2316-2329, 2020.

[13] W. Zima, P. Dziewa, "Modelling of liquid flatplate solar collector operation in transient states", Proc. IMechE Part A: J. Power and Energy, Vol. 225, Issue: 5, pp.53-62. Feb. 2011.

[14] I. A. Duffie, W. A. "Beckmann, Solar engineering of thermal processes", 3rd edition, Wiley Interscience, New York, 2006.

[15] K. G. T. Hollands, T. E. Unny, G. D. Raithby, L. Konicek, "Free convective Heat Transfer Across Inclined Air Layers", Journal of Heat Transfer, Vol. 190, pp. 189-193, 1976.

[16] S. ÖZERINCÇ, "Heat transfer enhancement with nanofluids", Middle East Technical University, M.Sc. Thesis 2010.

[17] F.P. Incropera, D.P. Dewitt, T.L. Bergman, V.S. Lavine, "Fundamentals of Heat and Mass Transfer", sixth ed., 2006. 
[18] Y. Xuan, Q. Li, "Investigation on convective heat transfer and flow features of nanofluids", Journal of Heat Transfer, Vol. 125, pp.151-155, Feb. 2003.

[19] 19-https://ec.europa.eu/jrc/en/pvgis.

[20] M. S. Al-Hafidh, M. U. Al-Refaii, M. A. AlRawi, "Utilization of Solar Energy to Reduce Residential Load", NuRER 2012-III. International Conference on Nuclear \& Renewable Energy Resources, İstanbul, TURKEY, pp. 20-23, May 2012.

\section{تحسين اداء مجمع شمسي ذو لوح مستوي باستعمال مائع نانوي كمائع تشغيل \\ عمر محمد حمدون}

eng.omar.m.hamdoon@uomosul.edu.iq

جامعة الموصل ـ كلية الهندسة ـ قسم انهندة الميكانيكية

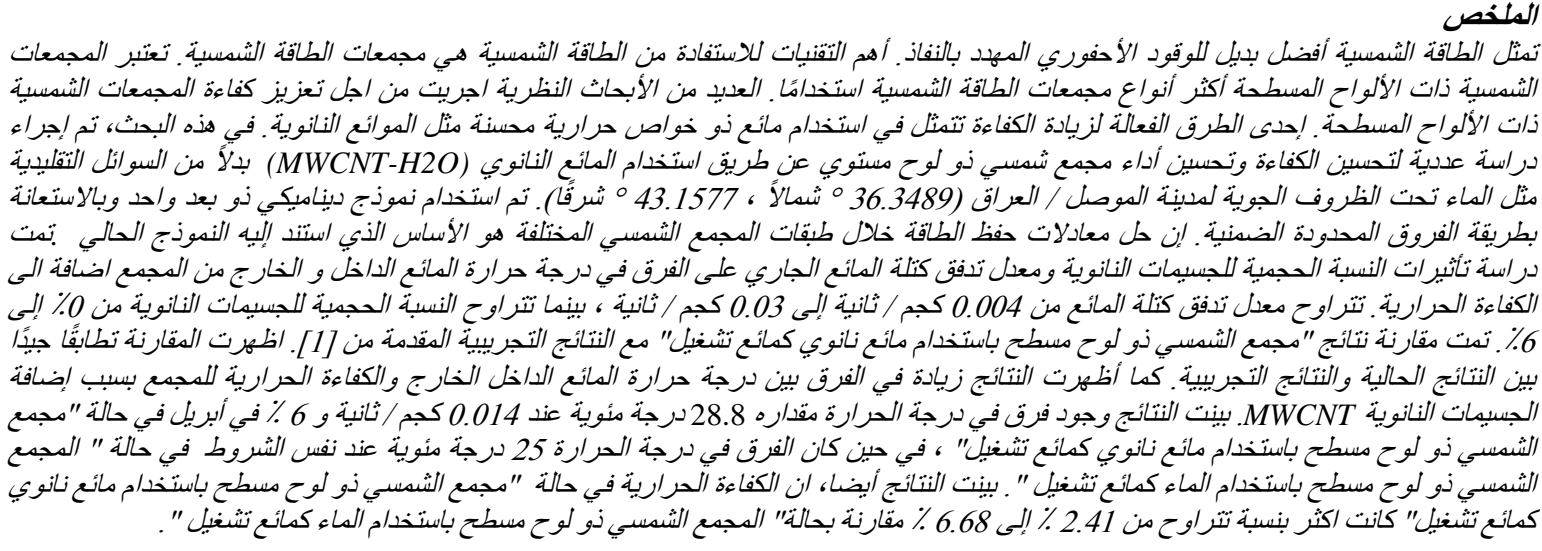

الكلمات اللدالله :

مناخ مدينة الدوصل، المجدع الشمسي ذو اللوح المستوي، المائع النانوي MWCNT-H 